\title{
Cellular Strategies of Axonal Pathfinding
}

\author{
Jonathan Raper $^{1}$ and Carol Mason ${ }^{2}$ \\ ${ }^{1}$ Departments of Neurosciences, and Cell and Developmental Biology, University of Pennsylvania, School of \\ Medicine, Philadelphia, Pennsylvania 19104-6058 \\ ${ }^{2}$ Departments of Pathology and Cell Biology, Neuroscience, and Ophthalmology, Columbia University, College \\ of Physicians and Surgeons, New York, New York 10032 \\ Correspondence: cam4@columbia.edu and raperj@mail.med.upenn.edu
}

\begin{abstract}
Axons follow highly stereotyped and reproducible trajectories to their targets. In this review we address the properties of the first pioneer neurons to grow in the developing nervous system and what has been learned over the past several decades about the extracellular and cell surface substrata on which axons grow. We then discuss the types of guidance cues and their receptors that influence axon extension, what determines where cues are expressed, and how axons respond to the cues they encounter in their environment.
\end{abstract}

$T^{\text {he }}$ his article provides an overview of how growth cones respond to the cellular substrata and molecular cues they encounter as they extend through the developing nervous system. It elaborates on the primer by Kolodkin and TessierLavigne (2010) and touches on many of the topics covered in greater detail in the articles that follow. The first sections describe how axons extend in a directed manner, the substrata on which they grow, interactions between pioneer and follower axons, and growth cone behaviors in emerging tracts and at decision points. The subsequent sections discuss examples of specific cues, their distributions, how their distributions are determined, and how growth cones integrate multiple cues during pathfinding.

\section{AXONS EXTEND IN VIVO IN A DIRECTED MANNER}

The first person to visualize the growing tips of axons, Ramon y Cajal, recognized that axons for the most part grow very efficiently towards their ultimate targets. He was a strong advocate for axons finding their way in response to chemotactic cues:

"If one admits that neuroblasts are endowed with chemotactic properties, then one might also imagine that they are capable of ameboid movements, initiated by factors secreted from epithelial, neural, or mesodermal elements. As a result, their processes may be oriented in the direction of chemical gradients, and thus guided to the secreting cells" (Ramon y Cajal 1892; trans. English, 1995).

This surprisingly modern outlook emphasizing directed guidance was temporarily derailed by the views of Weiss during the 1920s and 1930s. He first argued that functional specificity did not arise as a consequence of specific axonal connections (Weiss 1936), and later argued that nonspecific mechanical guidance cues play a predominant role in guiding axons and organizing them into nerves and tracts

Editors: Marc Tessier-Lavigne and Alex L. Kolodkin

Additional Perspectives on Neuronal Guidance available at www.cshperspectives.org

Copyright (C) 2010 Cold Spring Harbor Laboratory Press; all rights reserved; doi: 10.1101/cshperspect.a001933

Cite this article as Cold Spring Harb Perspect Biol 2010;2:a001933 
(Weiss 1934; Weiss 1945). These views were most effectively challenged by Weiss's student Sperry, who showed that regenerating retinal axons accurately reinnervate their original target locations in the frog tectum (Sperry 1943a,b; Attardi and Sperry 1963). He proposed that the retina and the tectum have a system of complementary chemical cues that help map the innervating axons onto their appropriate locations in the tectum (Sperry 1963). Subsequent work by many groups has shown that retinal axons compete amongst themselves in an activity dependent manner for tectal territory, and can thereby redistribute themselves within the target, but the basic finding that retinal axons initially prefer to grow to or branch in specific target locations has been vindicated by the discovery that counter gradients of Ephs and ephrins help establish retinotopy in visual centers (Cheng et al. 1995; Feldheim et al. 2000; Hindges et al. 2002; McLaughlin et al. 2003) (see Feldheim and O'Leary 2010).

Cajal's intuition that axons extend in a directed manner has proven to be prescient. In both invertebrate and vertebrate systems, the first axons to extend in the developing nervous system grow along highly stereotyped routes to form a reproducible scaffold of nerves and tracts. This was nicely shown, for example, in chick embryos by Cajal's student Tello (1923) and by Windle and Austin (1935). More recently, similar studies have been performed in zebrafish embryos (Chitnis and Kuwada 1990; Wilson et al. 1990; Ross et al. 1992). Typically these early pathways are pioneered by groups of axons that grow in a poorly fasciculated ribbon that becomes thickened over time as follower axons are added into each tract. These observations of highly invariant axonal outgrowth during early embryonic times leads to the inescapable conclusion that axons are actively guided to their targets. Not only must specifically localized guidance information be available in the developing nervous system, but axons must have a mechanism through which they can detect and respond appropriately to these guidance cues (Fig. 1).

\section{PIONEER NEURONS}

In any developing axon tract, the first extending axons will necessarily pioneer the route that all axons in the tract will ultimately traverse. Are the pioneers a specialized class of neurons with special properties, or do they have the same properties as all of their followers? Invertebrate neurons are individually identifiable, and thus the growth cones of specific neurons can be repeatedly observed in multiple individual animals. It was thus possible to show in both the peripheral and central nervous systems of insect embryos that particular growth cones travel along very precise trajectories through reproducible and defined choice points. For example, peripheral axonal pathways in the antenna, the leg, and the cerci are established by pairs of early differentiating axons called pioneers, which extend along stereotyped pathways into the CNS (Bate 1976; Edwards 1977; Keshishian 1980). These pioneers are necessary for the normal pathfinding of subsequently growing axons (Edwards et al. 1981; Klose and Bentley 1989). Reproducible deflections in pioneer trajectories within the leg correlate with the locations of specific early differentiating sensory cells, and deletion of these cells induce abnormal pioneer pathfinding (Bentley and Caudy 1983). These intermediary cells were thus termed "landmark" or "guidepost" cells because they provide navigational information to the pioneers. Particularly in the leg, however, it does not appear that a single pair of pioneer axons establishes connectivity between the distal-most periphery and the central nervous system de novo. Instead, the axons of an array of pioneer neurons pioneer short segments of the overall pathway while simultaneously acting as guidepost cells to more distal pioneers (Ho and Goodman 1982). The overall pattern of peripheral connectivity is produced by the cascading fasciculation of these many axons into peripheral nerves. The results of these studies suggested that pioneers prefer to extend from distal to proximal within the appendage, and their distinctive trajectories result in part from growing from guidepost to guidepost cell (Berlot and Goodman 1984). 
A

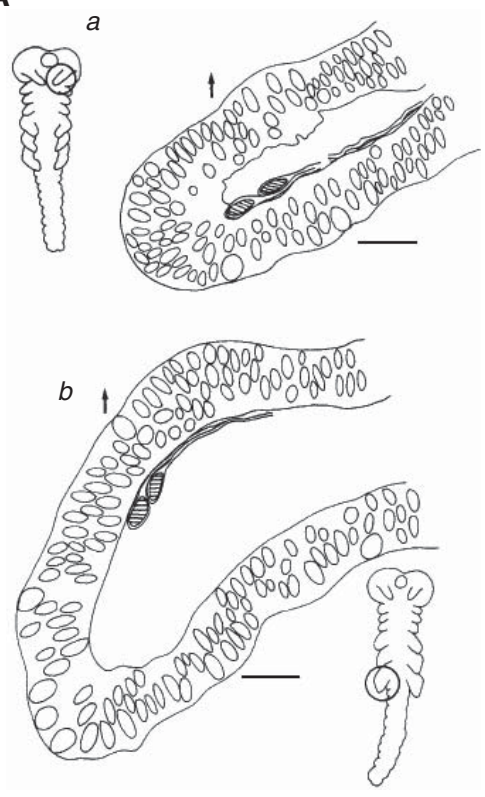

B

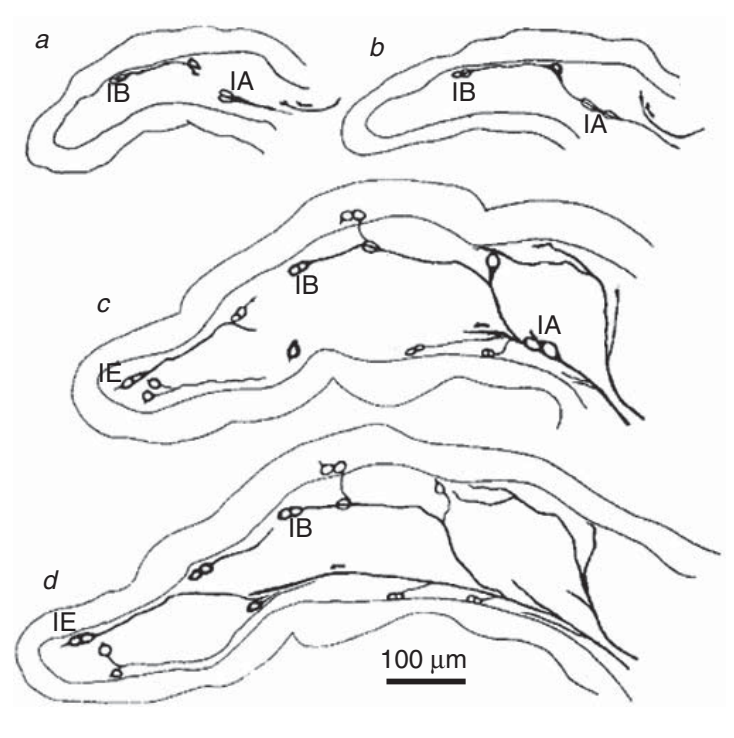

\section{C}
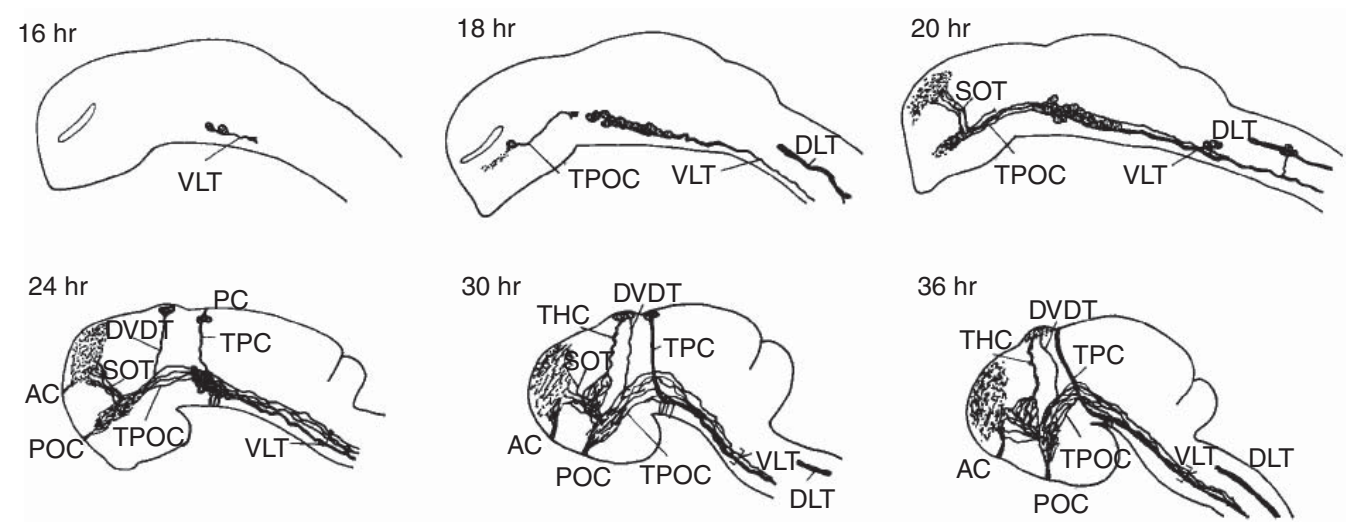

Figure 1. Early axon tract formation in the peripheral and central nervous systems. (A) The axons of the first neurons to differentiate in grasshopper antennae $(\mathrm{A} a)$ and legs $(\mathrm{A} b)$ grow between the surface epithelium and a basement membrane to pioneer axonal pathways from the periphery into the central nervous system. $(B a-d)$ As the limb develops further, progressively more distal neurons differentiate and pioneer short segments of peripheral nerve before fasciculating with more proximal pathways pioneered earlier. $(C)$ In the developing zebrafish CNS, the axons of later differentiating neuronal populations (24-36 h) add onto the earliest axonal pathways $(16-20 \mathrm{~h}$ ), forming a progressively elaborated axonal scaffold over time. $(A$, Reprinted, with permission, from Bate 1976 [C Nature Publishing Group]; B, reprinted, with permission, from Ho and Goodman 1982 [C Nature Publishing Group]; C, reprinted, with permission, from Ross et al. 1992 [(C) Society for Neuroscience].) 
A similar process applies to the highly reproducible nature of axonal trajectories in the insect CNS. Specific identifiable central pioneer axons are the first to extend on stereotyped pathways and reproducibly interact closely with, and are guided by, specific neuronal and glial partners (Taghert et al. 1982; Bastiani and Goodman 1986; Hidalgo and Booth 2000). Pioneer axons fasciculate with one another to form a scaffold on which subsequent axons extend (Raper et al. 1983b). Axons that extend on a common pathway can diverge from one another at reproducible choice points to join specific axonal bundles in the scaffold (Raper et al. 1984; Bastiani et al 1984). Deletion of neurons that produce a particular bundle disrupt the navigation of axons that would normally join the missing bundle (Raper et al. 1984). Different growth cones were shown to make divergent choices at the same choice points, demonstrating that each can respond to the same guidance cues in a cell specific manner (Raper et al. 1983a). These findings highlighted the precision with which axons extend in the developing CNS and some of the very specific cellular interactions that provide axonal guidance information (Fig. 2).

The act of naming the first extending axons "pioneers" did not endow them with special properties lacking in other neurons. Their ablation often perturbs the guidance of subsequent follower axons, either by delaying or misrouting them, but does not necessarily prevent followers from extending and locating their appropriate targets (Durbin 1987; Edwards et al. 1981; Pike et al. 1992; Hutter 2003). As a rule pioneers contribute guidance information and a suitable substratum for extension to their followers, but only in rare cases are they essential for followers to reach their targets (Whitlock and Westerfield 1998; Pittman et al. 2008). These findings are generally borne out by studies of pioneer axons in the developing retinal-tectal projections of vertebrates. Retinal pioneers normally originate in the dorsal half of the Xenopus eye, but when dorsal half eyes are replaced with less mature dorsal half eyes, axons arising from the ventral half eye can pioneer the connection between the eye and tectum without apparent difficulty
(Holt 1984). More recently, it has been shown that suppressing early retinal pioneer outgrowth by inhibiting the differentiation of the first retinal ganglion cells in zebrafish eyes prevents subsequent axons from exiting the eye (Pittman et al. 2008). This could imply that retinal pioneers have special pathfinding abilities, but could more simply be explained by the closer proximity of the pioneers to cues near the point at which they exit the eye. This same study used an elegant transplantation technique to show that pioneers missing an important guidance receptor induce normal follower axons to grow on aberrant trajectories, whereas normal pioneers tend to suppress pathfinding errors made by mutant follower axons. These findings are in agreement with the results from invertebrate studies showing that pioneers provide essential information that follower axons use for normal pathfinding. In general, pioneers establish a basic axonal scaffold early while embryos are small, distances are short, and the necessary guidance cues are close together. Follower axons can respond to some or all of the cues that the pioneers use to navigate, but the followers' ability to navigate efficiently is enhanced by cues provided by the pioneers.

\section{SUBSTRATA IN VIVO}

Harrison was the first to show that axons require a solid substratum on which to extend in vitro (Harrison 1910), and even though Weiss was too quick to dismiss the possibility that chemotropic cues guide axons to their targets, he performed a number of clever tissue culture experiments demonstrating that the orientation of fibrillar and substratum features can strongly orient axonal processes (Weiss 1934; 1945). When examined in vivo, some of the very first axons growing out into the CNS and PNS extend through spaces formed between other cells. In the mid-1970s Marcus Singer and colleagues championed the idea that these physical channels-interstitial spaces created by clearings amongst radial processes of the ependyma and germinal neuroepithlium — serve as a "blueprint” for axonal growth (Singer et al. 1979). By electron microscopy, the spaces seem to be 

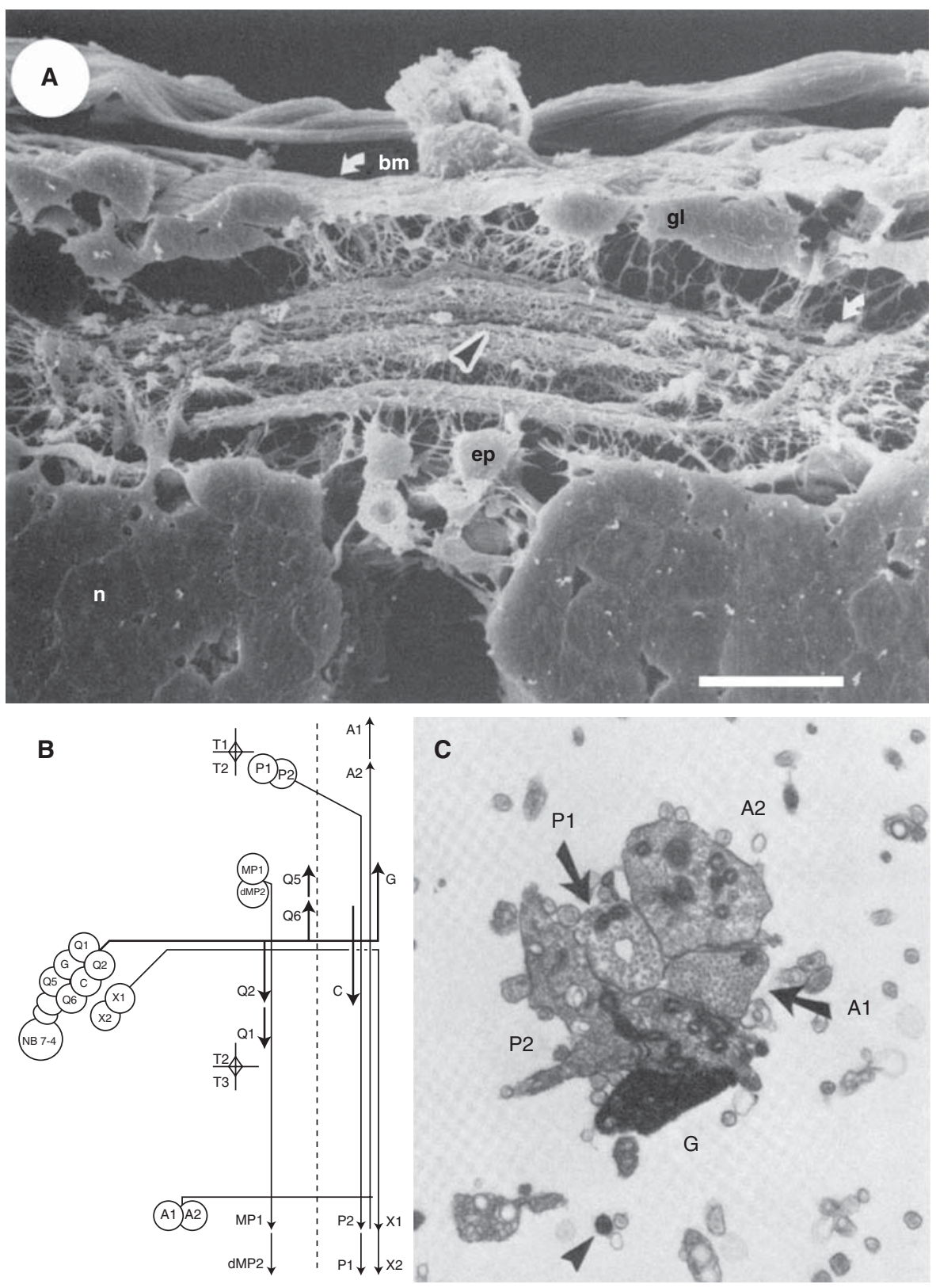

Figure 2. Selective fasciculation in the CNS of the developing grasshopper. (A) Axons are highly fasciculated in the developing grasshopper CNS as visualized by a scanning electron micrograph of the posterior segmental commissure. Specific axons extend within particular bundles. The arrowhead indicates the bundle in which axons growing from the $\mathrm{G}$ and $\mathrm{C}$ neurons extend. (bm) basement membrane, (gl) glia, (ep) epidermal cells, (n) neurons, scale bar $20 \mathrm{~mm}$. (B) A schematic showing the fasciculation patterns of axons extending from the first neurons born from neuroblast 7-4. The third and fourth born neurons, G and $C$, extend axons across the midline to a lateral position in the contralateral neuropil and then extend on a specific reproducible axon fascicle that contains the A1, A2, P1, and P2 axons. $(C)$ A transmission electron micrograph of the fascicle containing the G, C, A1, A2, P1, and P2 axons. The G axon was filled with HRP. (A, Reprinted, with permission, from Raper et al. 1983; B, C, reprinted, with permission, from Bastiani et al. 1984 [all (C) Society for Neuroscience].) 
filled with "light amorphic material" (Nordlander and Singer 1982). Although the spaces are presumably filled with fluid and other matrix components, as expected from the earlier observations in vitro, growth cones do not "swim" through such spaces and instead are apposed to surfaces of adjoining cells (Fig. 3B,C). The molecular attributes of the channels and their inner surfaces have not been characterized, and this phenomenon has gone unstudied since these observations were made in the 1970s and 1980s.

During the earliest periods of axon growth, young axons, even followers, relate to glial cells. Older axons tend to lie deeper within fiber bundles. Primitive glial processes accompany growth cones exiting the ventral spinal cord during ventral root formation, and Schwann cells enfold dorsal root ganglion cell axons just as they invade the dorsal neural tube (Tennyson 1970; Nordlander et al. 1981) (Fig. 3A). Similarly, just before the corpus callosum forms, primitive glial cells migrate medially from the ependymal zones of each hemisphere and through the fused walls of the dorsal septum, laying down a transient roadway termed the glial "sling." The pioneer axons of callosal fibers then extend on the sling (Silver et al. 1982, 1993) (See Chédotal and Richards 2010). In his observations on living nerves in the intact tadpole, Speidel found that dividing sheath cells and fibroblasts appeared to have a growth stimulating effect on extending axons (Speidel 1933), but the molecular nature of these cells in their primitive state is not known. In the optic nerve retinal ganglion cell axonal growth cones interpose among other previously extended axons and/or glial processes that increasingly enfold and subdivide axonal bundles (Colello and Guillery 1992) (Fig. 3D). As retinal axons approach the optic chiasm and tract, the youngest axons exit the bundles enfolded by such interfascicular glia and extend on and amongst radial glial end feet, with the youngest axons always closest to the pial basal lamina where the glial end feet attach (Colello and Guillery 1998; Stuermer and Bastmeyer 2000). In the fly visual system, a two-way neuron-glial interaction ensures proper axon outgrowth and glial enfolding of axons. As photoreceptor axons grow out, glia require a signal from the neurons to migrate back along the axons. Neurons in turn depend on the glial cells for proper guidance to exit the eyestalk (Rangarajan et al. 1999; Hummel et al. 2002). Areas of future study might include whether young glia in tracts in vivo have specialized molecules for axon extension, and to what extent neurons signal glial migration and process extension around axon fascicles.

Whereas peripheral pioneer axons grow on epithelial surfaces, follower axons in vivo display an avid preference for other axons (Speidel 1933). Wigglesworth (1953) showed that axons generally prefer other axons by damaging axons and observing that they grew back on themselves. Fasciculation of axons enables the younger axons of a given population within the same trajectory to add onto the tracts laid down by pioneer and older axons. During midline crossing in the fly CNS, homotypic axons from opposite sides of the neuraxis meet and grow along each other's surfaces, an interaction that is required for midline crossing (Myers and Bastiani 1993). Reordering of axon subpopulations can occur along pathways through changes in fasciculation, such as when retinal ganglion cell axons from nasotemporal and dorso-ventral retinal quadrants shift their relative positions as they the extend through the optic chiasm (Chan and Chung 1999) and when bundles of retinal axons shift positions as they extend in the optic tract (Walsh and Guillery 1985). The reasons for these shifts are not understood.

Axon-axon interactions are critical for organizing axons into smaller bundles to facilitate proper topographic targeting later in the trajectory. In the fly eye, homophillic adhesive interactions bind together axons within the same ommatidial bundle (Chen and Clandinin 2008). In all of these instances, homotypic axon-axon interactions function to keep like axons together. In addition, antifasciculation interactions between heterotypic axon bundles ensure proper segregation of unlike axon fascicles so that they can extend to different targets. For example, EphA receptors on motor 

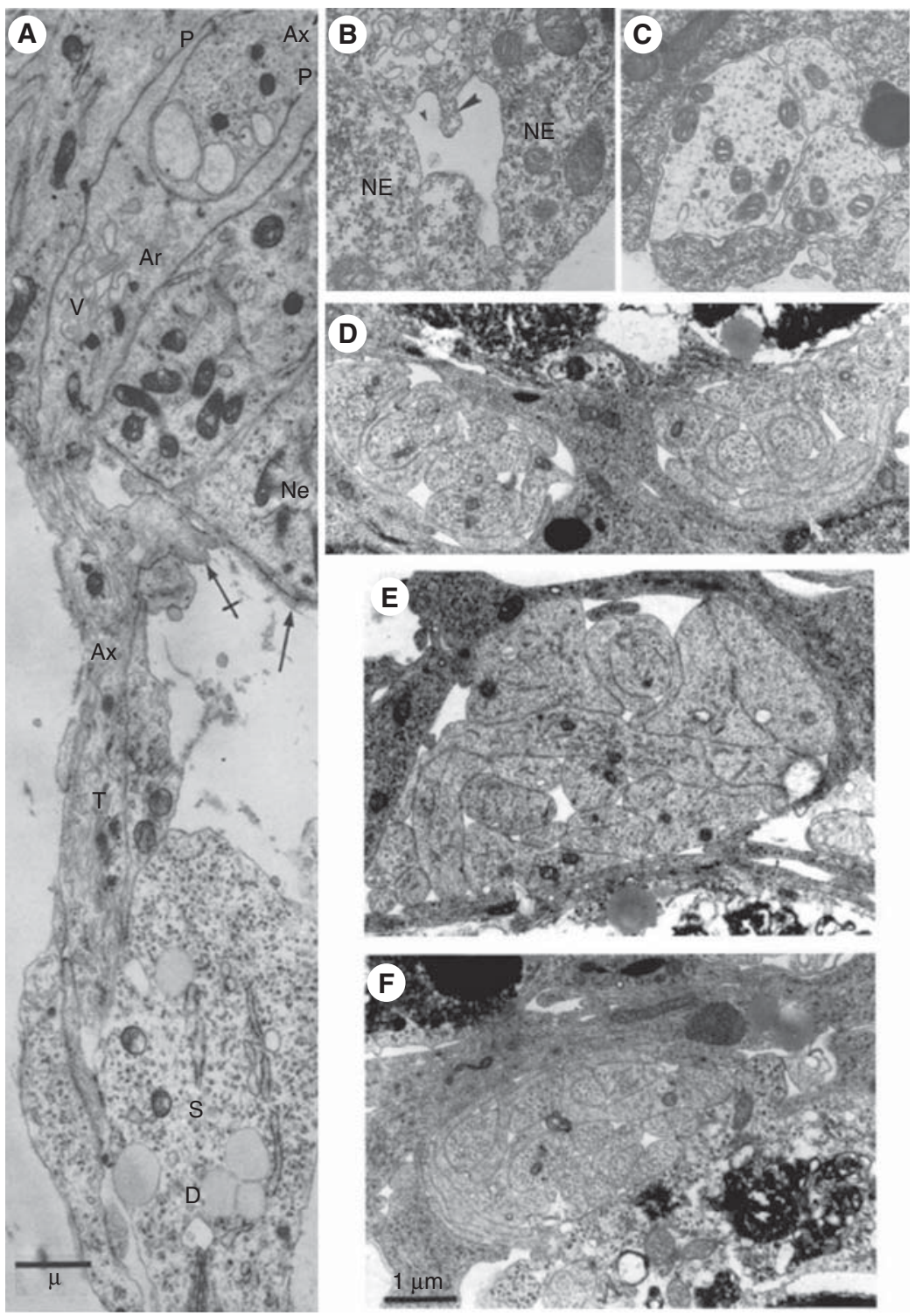

Figure 3. Axons grow in spaces formed by neuroepithelial cells, on other axonal surfaces, and in contact with immature glia. (A) An axonal growth cone enters the neural tube between epithelial cells ( $\mathrm{Ne}$ ) and its tip bifurcates into thin processes $(\mathrm{P})$ that surround a longitudinally extending axon (Ax). A Schwann cell ensheaths the axon but the axon looses this contact before it enters the neural tube. (rabbit, 11-12 days gestation). (B) Spaces or channels form between neuroepithelial cells at the neural tube stage. (C) A few axons course within the spaces formed by neuroepithelial cells (darker cytoplasm) as in B. (Stage 35 and 37, Xenopus). ( $D-F)$ E12 mouse embryo, bundle of axons extending in the optic stalk, surrounded by glia (darker cytoplasm). (D) The right bundle contains the flattened lamella of a growth cone of an axon (white arrow) growing adjacent to a glial cell. (E) The axon (white arrowhead) of this growth cone is also apposed to the glial cell; sections in D and E are 200 microns apart. (F) The bottom section is 100 microns more proximal to the retina than the middle section. Two other axons have interposed between the axon in $\mathrm{E}$ and the glial wrapping. ( $A$, Reprinted, with permission, from Tennyson 1970 [C Rockefeller University Press]; $B$, $C$, reprinted, with permission, from Nordlander and Singer 1982 [C Elsevier]; D-F, reprinted, with permission from Colello and Guillery 1992 [ (C) Wiley].) 
neuron axons prevent them from mingling with ephrinA-expressing sensory axons within axial nerves traveling to the muscles (Gallarda et al. 2008).

Growing axons prefer to grow on immature glia in emerging tracts and nerves, but they have distinct and often repulsive relationships with the glia at decision regions such as the midline of the forebrain, optic chiasm, and spinal cord. Various ensembles of immature radial glia, other noncanonical glia and transient neurons predominate at these sites (Marcus and Mason 1995; Lindwall et al. 2007) (See Chédotal and Richards 2010). Glial cells at midline loci express both inhibitory and growth-promoting guidance factors, and serve to cordon axons into their proper tracts and to prevent them from straying (e.g., Plump et al. 2002). Other molecules on midline glia are repulsive and induce some growth cones to turn away from the midline. Whether there are specific guidance factors that facilitate actual passage across the midline is not clear (See Dickson and Zou 2010). Glia and growth cones were thought to communicate via intercellular exchange of growth factors or modifiers of guidance factor expression (Rajagopalan et al. 2000; Yamamoto et al. 1990). As seen by ultrastructural analysis, retinal axon growth cones entering the optic chiasm midline intertwine with glial processes, and signs of intercellular interchange, such as coated vesicles, are prominent (Marcus et al. 1995) (Fig. 4). In the spinal cord, commissural axons appear to interact with side arms of the floor plate cells (Campbell and Peterson 1993), and in the insect CNS, the midline glia extend processes around bundles of commissural neurons, an interaction that is in part implemented by a specific form of neurexin (Stork et al. 2009).

As with guidepost cells in the insect limb, growth cones use neuronal cells as substrata and guides. In the vertebrate brain, cohorts of transient neurons serve this function. In the fish, retinal axons grow in contact with the axons of neurons comprising the tract of the postoptic commissure (Wilson et al. 1990). During optic chiasm formation in the mouse, a Vshaped raft of transient neurons form a template along and around which retinal axons grow but do not invade; the tip of the $\mathrm{V}$ intersects the specialized radial glia at the optic chiasm midline (Marcus et al. 1995; Marcus and Mason 1995). These early-born neurons are thought to guide both crossed and uncrossed retinal axons past the midline (Sretavan et al. 1994). The subplate cells in the developing cortex, a transient cell layer above the subventricular zone and below the emerging cortical layers, serve as a temporary way-station where axons pause before entering the emerging permanent cortical layers (Luskin and Shatz 1985; Ghosh and Shatz 1992). The subplate is crucial for proper guidance and afferent invasion of the cortex (Catalano and Shatz 1998; Kanold et al. 2003). The subplate is similar to the chiasmatic neurons described above, in that these cell groups disappear (or transit into other cell types) as the brain matures. Both chiasm and subplate cells have unique molecular features such as SSEA-1, an epitope generally associated with progenitor cells (Capela and Temple 2002). These findings indicate that transitory cell populations can serve an important guidance role even though they have no function in the mature nervous system.

Ramon y Cajal pointed out that variations in growth cone morphology reflect the cellular and "chemical" environment in which growth cones extend. Beginning in the 1970s, growth cone forms were chronicled in vitro during encounters with differing substrata or specific neuronal or glial cells (e.g., Letourneau 1975; Kapfhammer and Raper 1987; Bandtlow et al. 1990; Cooper and Smith 1992; Burden-Gulley et al. 1995). These studies provided an index for analyzing growth cone morphology and behaviors in vivo. In the mid 1980s, numerous studies based on dye-labeling, static and dynamic imaging, and EM of growth cones in invertebrates and vertebrates convincingly showed that growth cone morphology mirrors three general behaviors that are related to substrata and cellular environments through which they grow (e.g., Tosney and Landmesser 1985; Caudy and Bentley 1986; Bovolenta and Mason 1987; Norris and Kalil 1990; Kim et al. 1991). Torpedo-shaped growth cones, often with 

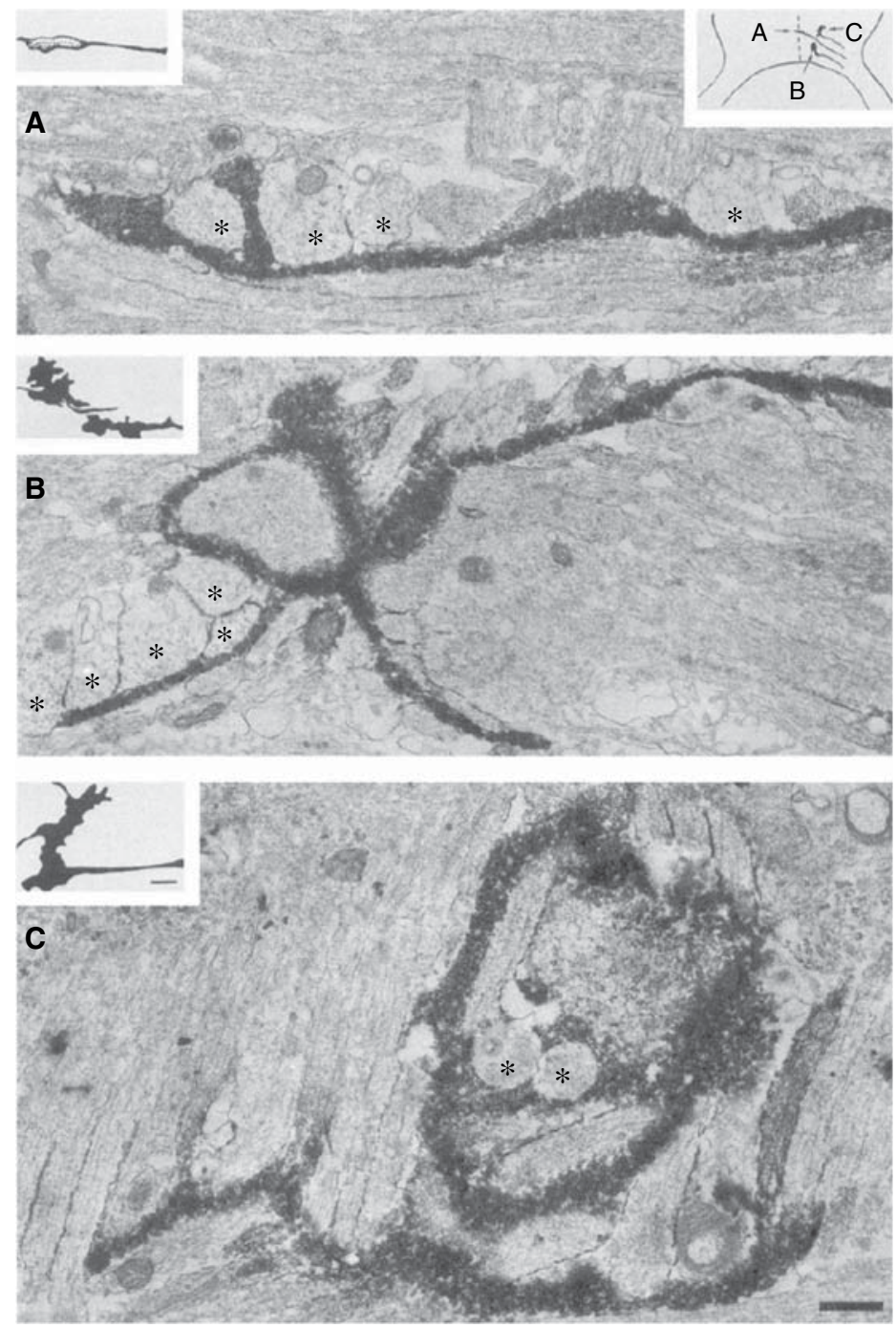

Figure 4. Growth cones contact radial glial processes at the optic chiasm midline. DiI labeled (black deposit) retinal axon growth cones grow in intimate contact with processes of the midline glial palisade (cut in cross section $\left.^{*}\right)$ after crossing the midline $(A)$, during pausing $(B$, inferred from the static image of a complex growth cone), and during a turn away from the midline $(C)$. Coated vesicles are prominent in the glial cells. (Reprinted, with permission, from Marcus et al. 1995 [ (C) Society for Neuroscience].)

convex and concave lamellar "wings" extending from a central shaft, are observed during extension on axon bundles in tracts in vivo. The lamellae dynamically wrap around axonal bundles. Growth cones become complex with numerous filopodia and an expanded body at sites where axon direction or cellular relationships change. These include choice points such as the midline, at plexi, and at the entry to target regions. Growth cones become complex when they pause from active extension yet filopodia continue to retract and extend. When an aversive cue is encountered, growth cones condense into smooth, appendage-free stumps, and often retract. Collapsed growth cones re-extend, repeat the cycle of protrusion and retraction, and eventually extend forward in the same or new direction (Sabry et al. 
1991; Godement et al. 1994; Mason and Wang 1997; Hutson and Chien 2002; Sakai and Halloran 2006). Changes in growth cone shape and behavior observed in vivo can thus herald a shift in the nature of the cues presented by the cellular and extracellular components in the path of a growing axon. However, only a few studies have related the behaviors of growth cones to the distribution of specific guidance molecules along pathways in vivo (e.g., Whitesides and LaMantia 1996).

\section{MOLECULAR GUIDANCE CUES}

The highly reproducible patterns of axonal outgrowth in developing embryos and the observed preferences of specific axons for particular substrata in vivo implies that axons are actively guided by information in their surrounding environment. This information must be specifically distributed reproducibly from embryo to embryo to produce repeatable patterns of axonal outgrowth. In principle, guidance information could take multiple forms ranging from electrical gradients, physical constraints, and localized molecular cues. Inspired in part by the ideas of Cajal and Sperry and the availability of powerful biochemical, molecular, and genetic techniques, the past two decades have seen a concerted effort to identify and characterize molecular signaling molecules that promote and guide axon extension. Although powerful in vitro assays have been developed to identify and characterize candidate cues, a bona fide guidance function can only be ascribed to a candidate cue by demonstrating that its loss in vivo induces axonal misprojections.

\section{Adhesive Cues}

For axons to extend in vitro, they require the presence of a permissive substratum on which to extend. Adhesive cues generally fall into two major categories, either particular extracellular matrix (ECM) components expressed in cellular interstices or basement membranes, and cell adhesion molecules (CAMs) expressed on nonneuronal or neuronal surfaces. These extension promoting substrate molecules are recognized by specific receptors on axonal growth cones that are in turn indirectly linked to the motile machinery within the growth cone (Suter and Forscher 2000) (See Gertler et al. 2010). Growth cones adhere to permissive substrata and exert force, such that they are more difficult to dislodge from the substratum when they are adherent (Heidemann and Buxbaum 1991). When presented with a choice of permissive and nonpermissive substrata arrayed in alternating stripes or a grid, the selective adherence of growth cone processes to the permissive substratum redirects the growth cone onto the permissive zone (Letourneau 1975).

An example of an ECM protein that promotes outgrowth is the basement membrane component laminin. Axonal extension on laminin and most other ECM components requires that growth cones express appropriate receptors largely from the integrin family (Bozyczko and Horwitz 1986; Jessell 1988; Letourneau et al. 1994; Huber et al. 2003). Neurons have preferences for different ECM substrata according to the subtypes of integrin receptors they express (McKerracher et al. 1996). Different families of ECM components can influence the effect of other components. For instance, proteoglycans (CSPG) can have different effects depending on whether they are presented on a laminin or fibronectin substrate (Snow et al. 1996). Likewise, heparin and glycoaminoglycans can inhibit the action of fibronectin (Carbonetto et al. 1983).

Neurons and glia express various combinations of a wide variety of CAMs that can mediate the adhesion of axons to themselves or other cellular processes. One major class of cell adhesion molecules thought to be important in axonal outgrowth is the Ig superfamily of CAMs including NCAM, fasciclins, NILE, TAG-1, DM-GRASP, and neurofascin. Another class is the calcium-dependent cadherins. Both IgCAMs and cadherins can bind homophilically, and many of the Ig-CAMs also bind heterophilically (Rougon and Hobert 2003; Schmid and Maness 2008). CAMs can be shown to promote axonal growth in vitro and different classes of neurons display preferences for different CAMs. 
Cell adhesion molecules promote adhesion by serving as indirect physical linkers connecting the outside environment to the internal cytoskeleton, and also serve as receptors that activate signaling processes, for example in the FAKMAPK pathways which further promote or impede motility (Williams et al. 1994; Bechara et al. 2007; Maness and Schachner 2007).

The results from antibody perturbation experiments in vivo are consistent with the idea that CAMs play important roles in axon fasciculation or guidance. NCAM and NgCAM have been implicated in promoting the fasciculation of retinal and spinal commissural axons respectively, whereas axonin-1 and NrCAM have been implicated in commissural and retinal axon pathfinding at the midline (Stoeckli and Landmesser 1995; Fitzli et al. 2000; Thanos et al. 1984; Williams et al. 2006). Pathfinding errors after genetic ablation of CAMs have been reported in a limited number of cases. For example, the Ig-superfamily molecule sidestep has an adhesive interaction with beaten path. Motor axons expressing beaten path extend along a pathway that expresses sidestep, and mutations in either molecular component can disrupt axon pathfinding (Siebert et al. 2009). Loss of DN-Cadherin in fly embryos induces defasciculation and misorientation of axons (Iwai et al. 1997). In null mouse mutants of Celsr3, an atypical cadherin/Drosophila flamingo homologue, the extension of subcortical projections to and within the cortex are impaired and cortex-specific inactivation impairs projections to the cortex (Zhou et al. 2008). In the L1 null mouse thalamocortical axons are hyper-fasciculated and make guidance errors (Wiencken-Barger et al. 2004). Loss of $\beta$ integrin leads to aberrant organization of the peripheral nervous system, in spinal nerve organization, and neuromuscular junction synaptogenesis (Pietri et al. 2004). These examples are not the norm as in the absence of single CAMs or ECM components, few defects are normally observed in neurons in axonal pathfinding or organization, such as in the loss of $\beta$ integrin in a conditional knockout mouse (Schwander et al. 2004). Further, these mutant phenotypes may not be explained by the loss of adhesive interactions per se, but instead may be ascribed to the proposed role of CAMs such as L1 or integrins as crucial accessory receptors involved in semaphorin signaling (Castellani et al. 2000; Pasterkamp et al. 2003; Bechara et al. 2007; Wolman et al. 2007; Law et al. 2008; Wang et al. 2008).

Because the expression of particular CAMs has the potential to determine selective axonaxon and axon-cell interactions in vivo, their study will likely be at the center of future efforts to understand growth cone guidance decisions at a cellular level. The challenge lies in how to genetically manipulate CAMs and ECM molecules, spatially and temporally, singly and in various combinations, to better understand their role.

\section{Trophic Signals}

Trophic signaling molecules promote neuronal survival, growth cone motility, and axon outgrowth. One example is the neurotrophins (Reichardt 2006). Trophic signals help stimulate growth cone motility (Connolly et al. 1985), and steep gradients of neurotrophins can orient axonal outgrowth in vitro (Letourneau 1978; Gundersen and Barrett 1979). Thus far, neurotrophins have not been found to have a profound effect on axon directionality in vivo (e.g., O'Connor and Tessier-Lavigne 1999), but they may act as short range attractants once axons come very close to their targets (Patel et al. 2000; Genç et al. 2004). Other trophic factors have been proposed to play important guidance roles. Insulin-like growth factor (IGF) has been proposed to act as a chemoattractant for olfactory axons (Scolnick et al. 2008). Hepatocyte growth factor (HGF) promotes the survival of motor neurons, is expressed in branchial arches, is required for normal extension of the hypoglossal nerve, and attracts cranial motor axons in vitro (Ebens et. al. 1996; Caton et al. 2000). Even so, our current understanding suggests that the most general function of trophic factors is to promote the stabilization and survival of neurons and their processes once they have made connections 
with their appropriate targets (Reichardt 2006; Marshak et al. 2007).

\section{Tropic Guidance Cues}

Tropic cues impart a directional valence to growth cone motility, acting as either attractants or repellents. The chemotactic cues hypothesized by Cajal would fall into this category. For example, Semaphorin3A acts as a secreted repellent that prevents entry of early arriving olfactory axons into the chick olfactory bulb (Luo et al. 1993; Renzi et al. 2000), or in the mouse olfactory system, helps to map sensory axons from the epithelium onto specific regions of the olfactory bulb (Schwarting et al. 2000; Taniguchi et al. 2003; Imai et al. 2009). Netrin/ unc6 is a secreted chemotactic signal produced at the ventral midlines of both vertebrates and invertebrates. It attracts one subset of axons while repelling another, helping to determine whether axons extend either ventrally or dorsally (Hedgecock et al. 1990; Kennedy et al. 1994; Colamarino and Tessier-Lavigne 1995; Wadsworth et al., 1996). In the vertebrate spinal cord, netrin is expressed in non-neuronal cells at the floor plate at the ventral midline and one of its key receptor components, DCC, is expressed in commissural axons. Both netrin and DCC are essential for commissural axons to reach the ventral midline in the vertebrate spinal cord (Serafini et al. 1996; Fazeli et al. 1997).

Secreted tropic cues can act at a distance, as netrin does, to establish gradients of information. Alternatively, guidance cues can be tightly linked to cell surfaces and influence only growth cone processes that make contact with them. For example, the Ig-superfamily member DSCAMs are transmembrane signaling molecules. In insects, the DSCAM1 gene can be differentially spliced into potentially tens of thousands of isoforms (Schmucker et al. 2000). The processes of a neuron expressing a particular collection of isoforms is repulsed by its own process in a DSCAM1 dependant manner, but mix freely with neuronal processes expressing disparate DSCAM1 isoforms (Hughes et al. 2007; Matthews et al. 2007;
Soba et al. 2007). Many of the guidance cues in the semaphorin family and all of those in the ephrin family are transmembrane or surface bound molecules. However, even surface localized guidance cues can be used to generate a gradient of guidance information. For example, gradients of ephrin expression in the tectum and superior colliculus help organize the retinotopic projections of retinal ganglion cells onto their target fields (Cheng et al. 1995; Feldheim et al. 2000; Hindges et al. 2002; McLaughlin et al. 2003; O’Leary 2010).

\section{Modulatory Guidance Cues}

Modulatory cues affect how axons respond to tropic cues without acting as tropic cues on their own. Possible examples of this kind of cue include laminin, NGF, or the chemokine SDF1. For example, netrin can be converted from an attractant to a repellent depending on whether growth cones are extending on fibronectin or laminin (Hopker et al. 1999). Neurotrophins or the chemokine SDF1 can make axons less responsive to the repellent semaphorin3A (Dontchev and Letourneau 2002; Chalasani et al. 2003a). One signaling pathway through which modulators can influence growth cone responses to tropic cues is by altering cyclic nucleotide concentrations within the responding growth cone (Song et al. 1997), implying that the internal state of the growth cone can have a profound effect on its responses to tropic guidance cues.

\section{The Limits of Categorization}

Individual molecular guidance cues can span several of these categories depending on the particular context in which they act. For example, the chemokine SDF1 acts as a chemoattractant for migrating dentate granule cells in the hippocampus, a trophic factor for retinal neurons, and a potential modulator cue that makes retinal axons less sensitive to repellents (Bagri et al. 2002; Chalasani et al. 2003b; Chalasani et al. 2003a). Some of the tropic guidance molecules have a significant influence on other aspects of development such as cell survival. 
Netrin receptors can stimulate neuronal death when netrin is absent (Llambi et al. 2001) whereas semaphorin3A acting through its receptor Plexin-A3 for long periods can promote sensory neuron death (Ben-Zvi et al. 2008). Tropic cues can play fundamentally important roles in determining cell fates during development. For example, Wnt4 helps guide commissural axons anteriorly after they cross the ventral midline of the developing spinal cord (Lyuksyutova et al. 2003), but is also an important determinant of cellular differentiation in the mammalian reproductive system (Vainio et al. 1999; Kim et al. 2006). Thus, axonal guidance cues are not specialized for any one function, nor do they act through a single mechanism. They are potent signals that have different effects depending on the developmental contexts in which they act.

\section{DISTRIBUTION AND REGULATION OF GUIDANCE RECEPTORS AND CUES}

Axonal trajectories are determined by the combined influence of the guidance receptors expressed on axon surfaces and the distributions of relevant cues axons encounter in their environment. As a consequence, accurate pathfinding depends critically on the establishment of reproducible and precise patterns of expression for both receptors and guidance cues. Subpopulations of neurons whose axons make divergent decisions at choice points express different sets of receptors for guidance cues. These cues are expressed in a spatially and temporally discontinuous manner along axon pathways. Transcription factors control receptor expression in the growing neuron and guidance cue expression in the surrounding pathways. These principles are well illustrated in the vertebrate motor and retinal projections.

Motor neurons innervating limb muscles arise from brachial and lumbar levels of the spinal cord and are positioned in medial and lateral subdivisions of the lateral motor column (LMC). Distinct subdivisions of the LMC innervate specific muscle targets in the limb (Landmesser 1978). Motor axons must choose between separate dorsal or ventral pathways to reach their correct muscles. Motor neuron identity is determined by a combinatorial code of LIM transcription factors (Jessell 2000). Lhx1 (Lim1) is expressed in lateral LMC motor neurons which project to the dorsal limb, whereas Isl1 is expressed in medial LMC neurons, which project to the ventral limb (Kania et al. 2000). Lateral LMC motor axons project into the dorsal limb because they express EphA receptors and are repulsed by high levels of ephrinA5 in the ventral limb (Kania and Jessell 2003). Medial LMC axons project into the ventral limb because they express EphB receptors and are repulsed by ephrinB2 in the dorsal limb (Luria et al. 2008). Lhx1 regulates EphA4 expression in lateral LMC motor neurons, Islet1 regulates EphB in medial LMC motor neurons, and Lmxlb, expressed in the dorsal limb, promotes expression of ephrinA5 and ephrinB2 expression in the dorsal limb mesenchyme (Kania and Jessell 2003; Luria et al. 2008; Bonanomi and Pfaff 2010). Thus, a complimentary system of Eph receptors and their ligands directs motor neuron axons to distinct target regions, and the expression of key guidance components in each pathway is regulated by specific LIM homeodomain transcription factors.

In the visual projection of vertebrates with stereoscopic vision, specific subsets of retinal ganglion cell axons project ipsilaterally or contralaterally at the optic chiasm before projecting to targets in the thalamus. Retinal ganglion cells in the ventrotemporal retinal crescent project ipsilaterally, whereas ganglion cells outside of the ventrotemporal retina and some late-born cells in the ventrotemporal retina project contralaterally (Godement et al. 1990; Guillery et al. 1995). In both the frog and mouse, ephrinBs expressed by glial cells at the midline force ventrotemporal retinal ganglion cell axons expressing EphB receptors to the ipsilateral side of the chiasm (Nakagawa et al. 2000; Williams et al. 2003). The timing of receptor and ligand expression and subsequent downregulation is exquisite (Williams et al. 2003). The transcription factor Zic2 regulates EphB1 expression in ventrotemporal retinal ganglion cells, it is required for the ipsilateral projection, and it is sufficient to induce an ipsilateral 
trajectory in contralaterally-projecting cells (Herrera et al. 2003; Garcia-Frigola et al. 2008; Lee et al. 2008). The transcription factor Foxd1, in turn, seems to regulate the expression of Zic2, as mutations in Foxd1 lead to an absence of Zic2 and EphB1 expression (Herrera et al. 2004).

As in the retina, transcription factors expressed in the ventral diencephalon where the optic chiasm forms control guidance cue expression. In the Foxd1 mutant mouse (Marcus et al. 1999; Herrera et al. 2004), and the Belladonna (Lhx2) mutant zebrafish (Seth et al. 2006), ipsilateral retinal projections are greatly increased because of the misexpression around the optic chiasm of both transcription factors and guidance cues including Zic2, Foxg1, Slits, and Ephs. After retinal axons enter the optic tracts, patterned transcription factors in the retina control the expression of Ephs and ephrins that are used to topographically map retinal axons onto the tectum (See Huberman et al. 2010; O'Leary 2010).

These examples illustrate the principle that the precise and sequential expression patterns of transcription factors determine the expression of both guidance receptors and their cues. The mechanisms underlying the control of guidance factor expression by transcription factors are just beginning to be identified in these and other systems (e.g., Wilson et al. 2008; Takahashi et al. 2009). Multiple guidance receptors and cues are expressed in overlapping but distinct patterns, and how these patterns of expression are coordinated amongst the transcription factors themselves is another challenging problem.

\section{INTEGRATION OF GUIDANCE INFORMATION}

It is readily apparent that axons extending through the developing nervous system encounter many competing guidance signals arising from a variety of sources that need to be integrated into unitary, reproducible decisions. Axons simultaneously interact closely with the ECM, glial, and neuronal cell surfaces, each of which express multiple permissive, tropic, and modulatory signals all at the same time (Fig. 5). Now that many of the key guidance molecules and their receptors have been identified, one of the great outstanding challenges is to understand how they work together to orchestrate the sequential guidance decisions of particular axons, from their point of initiation to the arrival
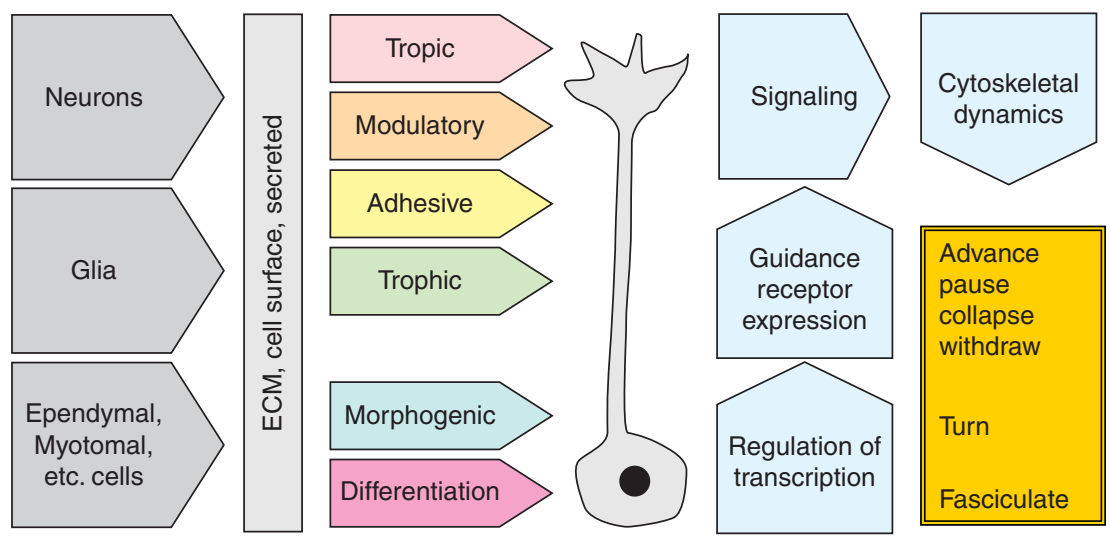

Figure 5. Environmental influences on axon pathfinding. Axons navigate through an environment in which neuronal and non-neuronal cells display on their surfaces or secrete into interstitial spaces and the ECM a variety of signaling molecules. These include morphogenic and differentiation factors that influence neuron determination, as well as tropic, modulatory, adhesive, and trophic factors that act directly on the growth cone. Depending on which specific guidance receptors and signaling components are expressed in the growth cone, guidance cues activate particular signaling pathways that regulate growth cone motility. As a result, a growth cone may advance, pause, collapse, withdraw, turn, or fasciculate with other axons. 
at their target. One system in which this issue has been studied in detail is at the invertebrate and vertebrate midlines (See Dickson and Zou 2010).

It might seem reasonable to assume that the effects of multiple attractive and repellent cues add together, producing a net effect in proportion to their sum. However, the information currently available suggests that this is not always the case and that important nonlinearities arise when multiple cues interact. The modulatory cues mentioned previously are examples, as they do not provide directional information on their own, but instead alter how axons interpret other tropic cues. Two very dramatic examples of cues whose effects do not simply sum together are provided by the coexpression of the attractant netrin and the repellent slit at the ventral midline of the vertebrate nervous system. Commissural axons are first attracted to the midline by netrin and then repelled away from the midline by slit. As commissural axons approach the midline their responsiveness to slits is thought to be suppressed by the expression of Robo-3/Rig-1, a Robo receptor relative that makes the expressing axons less sensitive to slits (Sabatier et al. 2004; Chen et al. 2008). Once commissurals reach the midline, Netrin/DCC attraction is reported to be silenced by slit activation of the Robo receptor and Robo's interaction with the intracellular domain of DCC (Stein and Tessier-Lavigne 2001). Commissural axons thereby loose their responsiveness to the midline attractor netrin so that they can be pushed away by slit. At the fly ventral midline, activation of the netrin receptor frazzled/ DCC by a netrin independent mechanism has been shown to down-regulate Robo expression through the activation of Commissureless (Yang et al. 2009). Commissureless-induced Robo receptor internalization helps netrin attract axons to the midline by making pre-crossing commissurals insensitive to the repellent effects of slit produced there (Keleman et al. 2002). These examples highlight the potential complexities in signal integration as growth cones encounter multiple guidance cues in their environment and show that competing signals cannot be assumed to simply sum linearly together.

\section{CONCLUSION}

Truly understanding how axons navigate so precisely to their targets will require a systematic description of the cells with which they interact, cataloguing the full menu of cues displayed and secreted by those cells, and understanding how growth cone responses are produced by the combined action of these cues. Spectacular progress has been made over the past decade in identifying and understanding how molecular guidance cues work, but less attention has been paid to the cellular context in which these cues are produced, presented, and interpreted by growing axons. Past experience suggests that the greatest progress towards these goals will be made by researchers brave enough to apply a multitude of different techniques ranging from electron microscopy through molecular and cellular biology, towards well defined in vivo systems in which specific axonal decisions can be recognized and understood in detail.

\section{ACKNOWLEDGMENTS}

JAR is supported by the NIH (NIDA) and CAM by the NIH (NEI), the Gatsby Foundation, and Human Frontier Science Program.

\section{REFERENCES}

Attardi DG, Sperry RW. 1963. Preferential selection of central pathways by regenerating optic fibers. Exp Neurol 7: 46-64.

Bagri A, Marín O, Plump AS, Mak J, Pleasure SJ, Rubenstein JL, Tessier-Lavigne M. 2002. Slit proteins prevent midline crossing and determine the dorsoventral position of major axonal pathways in the mammalian forebrain. Neuron 33: 233-248.

Bandtlow C, Zachleder T, Schwab ME. 1990. Oligodendrocytes arrest neurite growth by contact inhibition. J Neurosci 10: 3837-3848.

Bastiani MJGoodman CS. 1986. Guidance of neuronal growth cones in the grasshopper embryo. III. Recognition of specific glial pathways. J Neurosci 6: 3542-3551.

Bastiani MJ, Raper JA, Goodman CS. 1984. Pathfinding by neuronal growth cones in grasshopper embryos. III. Selective affinity of the $G$ growth cone for the $P$ cells within the A/P fascicle. J Neurosci 4: 2311-1228.

Bate CM. 1976. Pioneer neurones in an insect embryo. Nature 260: 54-56.

Bechara A, Falk J, Moret F, Castellani V. 2007. Modulation of semaphorin signaling by Ig superfamily cell adhesion molecules. Adv Exp Med Biol 600: 61-72. 
J. Raper and C. Mason

Bentley D, Caudy M. 1983. Pioneer axons lose directed growth after selective killing of guidepost cells. Nature 304: 62-65.

Ben-Zvi A, Manor O, Schachner M, Yaron A, TessierLavigne M, Behar O. 2008. The Semaphorin receptor PlexinA3 mediates neuronal apoptosis during dorsal root ganglia development. J Neurosci 28: 12427-12432.

Berlot J, Goodman CS. 1984. Guidance of Peripheral Pioneer Neurons in the Grasshopper: Adhesive Hierarchy of Epithelial and Neuronal Surfaces. Science 223: 493-496.

Bonanomi D, Pfaff SL. 2010. Motor axon pathfinding. Cold Spring Harb Perspect Biol 2: a001735.

Bovolenta P, Mason CA. 1987. Growth cone morphology varies with position in the developing mouse visual pathway from retina to first targets. J Neurosci 7: 1447-1460.

Bozyczko D, Horwitz AF. 1986. The participation of a putative cell surface receptor for laminin and fibronectin in peripheral neurite extension. J Neurosci 6: 1241-1251.

Burden-Gulley SM, Payne HR, Lemmon V. 1995. Growth cones are actively influenced by substrate-bound adhesion molecules. J Neurosci 15: 4370-4381.

Campbell RM, Peterson AC. 1993. Expression of a lacZ transgene reveals floor plate cell morphology and macromolecular transfer to commissural axons. Development 119: $1217-1228$.

Carbonetto S, Gruver MM, Turner DC. 1983. Nerve fiber growth in culture on fibronectin, collagen, and glycosaminoglycan substrates. J Neurosci 3: 2324-2335.

Castellani V, Chedotal A, Schachner M, Faivre-Sarrailh C, Rougon G. 2000. Analysis of the L1-deficient mouse phenotype reveals cross-talk between Sema3A and L1 signaling pathways in axonal guidance. Neuron 27: 237-249.

Catalano SM, Shatz CJ. 1998. Activity-dependent cortical target selection by thalamic axons. Science 281: 559-562.

Caton A, Hacker A, Naeem A, Livet J, Maina F, Bladt F, Klein R, Birchmeier C, Guthrie S. 2000. The branchial arches and HGF are growth-promoting and chemoattractant for cranial motor axons. Development 127: 1751-1766.

Capela ATemple S 2002. LeX/ssea-1 is expressed by adult mouse CNS stem cells, identifying them as nonependymal. Neuron 35: 865-875.

Caudy M, Bentley D. 1986. Pioneer growth cone morphologies reveal proximal increases in substrate affinity within leg segments of grasshopper embryos. J Neurosci 6: 364-379.

Chalasani SH, Baribaud F, Coughlan CM, Sunshine MJ, Lee VM, Doms RW, Littman DR, Raper JA. 2003b. The chemokine stromal cell-derived factor-1 promotes the survival of embryonic retinal ganglion cells. J Neurosci 23: 4601-4612.

Chalasani SH, Sabelko KA, Sunshine MJ, Littman DR, Raper JA. 2003a. A chemokine, SDF-1, reduces the effectiveness of multiple axonal repellents and is required for normal axon pathfinding. J Neurosci 23: 1360-1371.

Chan SO, Chung KY. 1999. Changes in axon arrangement in the retinofugal [correction of retinofungal] pathway of mouse embryos: Confocal microscopy study using single- and double-dye label. J Comp Neurol 406: $251-262$.
Chédotal A, Richards LJ. 2010. Wiring the brain: the biology of neuronal guidance. Cold Spring Harb Perspect Biol 2: a001917.

Chen PL, Clandinin TR. 2008. The cadherin Flamingo mediates level-dependent interactions that guide photoreceptor target choice in Drosophila. Neuron 58: 26-33.

Chen Z, Gore B, Long H, Ma L, Tessier-Lavigne M. 2008. Alternative splicing of the Robo3 axon guidance receptor governs the midline switch from attraction to repulsion. Neuron 58: 325-332.

Cheng HJ, Nakamoto M, Bergemann AD, Flanagan JG. 1995. Complementary gradients in expression and binding of ELF-1 and Mek4 in development of the topographic retinotectal projection map. Cell 82: 371-381.

Chitnis AB, Kuwada JY. 1990. Axonogenesis in the brain of zebrafish embryos. J Neurosci 10: 1892-1905.

Colamarino SA, Tessier-Lavigne M. 1995. The axonal chemoattractant netrin-1 is also a chemorepellent for trochlear motor axons. Cell 81: 621-629.

Colello RJ, Guillery RW. 1992. Observations on the early development of the optic nerve and tract of the mouse. J Comp Neurol 317: 357-378.

Colello SJ, Guillery RW. 1998. The changing pattern of fibre bundles that pass through the optic chiasm of mice. Eur J Neurosci 10: 3653-3663.

Connolly JL, Seeley PJ, Greene LA. 1985. Regulation of growth cone morphology by nerve growth factor: A comparative study by scanning electron microscopy. J Neurosci Res 13: 183-198.

Cooper MW, Smith SJ. 1992. A real-time analysis of growth cone-target cell interactions during the formation of stable contacts between hippocampal neurons in culture. J Neurobiol 23: 814-828.

Dickson BJ, Zou Y. 2010. Navigating intermediate targets: the nervous system midline. Cold Spring Harb Perspect Biol 2: a002055.

Dontchev VD, Letourneau PC. 2002. Nerve growth factor and semaphorin $3 \mathrm{~A}$ signaling pathways interact in regulating sensory neuronal growth cone motility. J Neurosci 22: 6659-6669.

Durbin RM. 1987. Studies on the development and organization of the nervous system of Caenorhabditis elegans. $\mathrm{PhD}$ thesis, University of Cambridge.

Ebens A, Brose K, Leonardo ED, Hanson MG Jr, Bladt F, Birchmeier C, Barres BA, Tessier-Lavigne M. 1996. Hepatocyte growth factor/scatter factor is an axonal chemoattractant and a neurotrophic factor for spinal motor neurons. Neuron 17: 1157-1172.

Edwards JS. 1977. Pathfinding by arthropod sensory nerves. In Identified neurons and behavior of arthropods (ed.) G Hoyle), pp. 484-493, Plenum, New York.

Edwards JS, Chen SW, Berns MW. 1981. Cercal sensory development following laser microlesions of embryonic apical cells in Acheta domesticus. J Neurosci 1: 250-258.

Fazeli A, Dickinson SL, Hermiston ML, Tighe RV, Steen RG, Small CG, Stoeckli ET, Keino-Masu K, Masu M, Rayburn $\mathrm{H}$, et al. 1997. Phenotype of mice lacking functional Deleted in colorectal cancer (Dcc) gene. Nature 386: 796-804. 
Feldheim DA, Kim YI, Bergemann AD, Frisén J, Barbacid M, Flanagan JG. 2000. Genetic analysis of ephrin-A2 and ephrin-A5 shows their requirement in multiple aspects of retinocollicular mapping. Neuron 25: 563-574.

Feldheim DA, O'Leary DDM. 2010. Topographic mapping: the visual system. doi: 10.1101.cshperspect.a001768.

Fitzli D, Stoeckli ET, Kunz S, Siribour K, Rader C, Kunz B, Kozlov SV, Buchstaller A, Lane RP, Suter DM et al. 2000. A direct interaction of axonin-1 with NgCAMrelated cell adhesion molecule ( $\mathrm{NrCAM}$ ) results in guidance, but not growth of commissural axons. J Cell Biol 149: $951-968$.

Gallarda BW, Bonanomi D, Muller D, Brown A, Alaynick WA, Andrews SE, Lemke G, Pfaff SL, Marquardt T. 2008. Segregation of axial motor and sensory pathways via heterotypic trans-axonal signaling. Science 320: 233-236.

Garcia-Frigola C, Carreres MI, Vegar C, Mason C, Herrera E. 2008. Zic2 promotes axonal divergence at the optic chiasm midline by EphB1-dependent and -independent mechanisms. Development 135: 1833-1841.

Genç B, Ozdinler PH, Mendoza AE, Erzurumlu RS. 2004. A chemoattractant role for NT-3 in proprioceptive axon guidance. PLoS Biol 2: 403. Epub 2004 Nov 23.

Gertler FB, Dent EW, Gupton L. 2010. The growth cone machine: biochemical regulators of the cytoskeleton. doi: 10.1101.cshperspect.a001800.

Ghosh A, Shatz CJ. 1992. Pathfinding and target selection by developing geniculocortical axons. J Neurosci 12: 39-55.

Godement P, Salaün J, Mason CA. 1990. Retinal axon pathfinding in the optic chiasm: Divergence of crossed and uncrossed fibers. Neuron 5: 173-196.

Godement P, Wang L-C, Mason CA. 1994. Retinal axon divergence in the optic chiasm: Dynamics of growth cone behavior at the midline. J Neurosci 14: 7024-7039.

Guillery RW, Mason CA, Taylor JS. 1995. Developmental determinants at the mammalian optic chiasm. J Neurosci 15: 4727-4737.

Gundersen RWBarrett JN. 1979. Neuronal chemotaxis: Chick dorsal-root axons turn toward high concentrations of nerve growth factor. Science 206: 1079-1080.

Harrison R. 1910. The outgrowth of the nerve fiber as a mode of protoplasmic movement. J Exp Zool 9: 787-846.

Hedgecock EM, Culotti JG, Hall DH. 1990. The unc-5, unc-6, and unc-40 genes guide circumferential migrations of pioneer axons and mesodermal cells on the epidermis in C. elegans. Neuron 4: 61-85.

Heidemann SR, Buxbaum RE. 1991. Growth cone motility. Curr Opin Neurobiol 1: 339-345.

Herrera E, Brown L, Aruga J, Rachel RA, Dolen G, Mikoshiba K, Brown S, Mason CA. 2003. Zic2 patterns binocular vision by specifying the uncrossed retinal projection. Cell 114: 545-557.

Herrera E, Marcus R, Li S, Williams S, Erskine L, Lai E, Mason C. 2004. Foxd1 is required for proper formation of the optic chiasm. Development 131: 5727-5739.

Hidalgo A, Booth GE. 2000. Glia dictate pioneer axon trajectories in the Drosophila embryonic CNS. Development 127: $393-402$.
Hindges R, McLaughlin T, Genoud N, Henkemeyer M, O'Leary DD. 2002. EphB forward signaling controls directional branch extension and arborization required for dorsal-ventral retinotopic mapping. Neuron 35: 475-487.

Ho RK, Goodman CS. 1982. Peripheral pathways are pioneered by an array of central and peripheral neurones in grasshopper embryos. Nature 297: 404-406.

Höpker VH, Shewan D, Tessier-Lavigne M, Poo M, Holt C. 1999. Growth-cone attraction to netrin-1 is converted to repulsion by laminin-1. Nature 401: 69-73.

Holt CE. 1984. Does timing of axon outgrowth influence initial retinotectal topography in Xenopus? J Neurosci 4: $1130-1152$.

Huber AB, Kolodkin AL, Ginty DD, Cloutier JF. 2003. Signaling at the growth cone: Ligand-receptor complexes and the control of axon growth and guidance. Annu Rev Neurosci 26: 509-563.

Huberman AD, Clandinin TR, Baier H. 2010. Molecular and cellular mechanisms of lamina-specific axon targeting. Cold Spring Harb Perspect Biol 2: a001743.

Hughes ME, Bortnick R, Tsubouchi A, Bäumer P, Kondo M, Uemura T, Schmucker D. 2007. Homophilic Dscam interactions control complex dendrite morphogenesis. Neuron 54: 417-427.

Hummel T, Attix S, Gunning D, Zipursky SL. 2002. Temporal control of glial cell migration in the Drosophila eye requires gilgamesh, hedgehog, and eye specification genes. Neuron 33: 193-203.

Hutson LD, Chien CB. 2002. Pathfinding and error correction by retinal axons: The role of astray/robo2. Neuron 33: $205-217$.

Hutter H. 2003. Extracellular cues and pioneers act together to guide axons in the ventral cord of C. elegans. Development 130: $5307-5318$.

Imai T, Yamazaki T, Kobayakawa R, Kobayakawa K, Abe T, Suzuki M, Sakano H. 2009. Pre-target axon sorting establishes the neural map topography. Science 325: 585-590.

Iwai Y, Usui T, Hirano S, Steward R, Takeichi M, Uemura T. 1997. Axon patterning requires DN-cadherin, a novel neuronal adhesion receptor, in the Drosophila embryonic CNS. Neuron 19: 77-89.

Jessell TM. 1988. Adhesion molecules and the hierarchy of neural development. Neuron 1: 3-13.

Jessell TM. 2000. Neuronal specification in the spinal cord: Inductive signals and transcriptional codes. Nat Rev Genet 1: 20-29.

Kania A, Jessell TM. 2003. Topographic motor projections in the limb imposed by LIM homeodomain protein regulation of ephrin-A:EphA interactions. Neuron 38: 581-596.

Kania A, Johnson RL, Jessell TM. 2000. Coordinate roles for LIM homeobox genes in directing the dorsoventral trajectory of motor axons in the vertebrate limb. Cell 102: 161-173.

Kanold PO, Kara P, Reid RC, Shatz CJ. 2003. Role of subplate neurons in functional maturation of visual cortical columns. Science 301: 521-525.

Kapfhammer JP, Raper JA. 1987. Collapse of growth cone structure on contact with specific neurites in culture. J Neurosci 7: 201-212. 
Keleman K, Rajagopalan S, Cleppien D, Teis D, Paiha K, Huber LA, Technau GM, Dickson BJ. 2002. Comm sorts robo to control axon guidance at the Drosophila midline. Cell 110: 415-427.

Kennedy TE, Serafini T, de la Torre JR, Tessier-Lavigne M. 1994. Netrins are diffusible chemotropic factors for commissural axons in the embryonic spinal cord. Cell 78: 425-435.

Keshishian H. 1980. The origin and morphogenesis of pioneer neurons in the grasshopper metathoracic leg. Dev Biol 80: 388-397.

Kim GJ, Shatz CJ, McConnell SK. 1991. Morphology of pioneer and follower growth cones in the developing cerebral cortex. J Neurobiol 22: 629-642.

Kim Y, Kobayashi A, Sekido R, DiNapoli L, Brennan J, Chaboissier MC, Poulat F, Behringer RR, Lovell-Badge R, Capel B. 2006. Fgf9 and Wnt4 act as antagonistic signals to regulate mammalian sex determination. PLoS Biol 4: 187.

Klose M, Bentley D. 1989. Transient pioneer neurons are essential for formation of an embryonic peripheral nerve. Science 245: 982-984.

Kolodkin A, Tessier-Lavigne M. 2010. Principles and molecules governing neural process guidance and branching: a primer. doi: 10.1101.cshperspect.a001727.

Landmesser L. 1978. The distribution of motoneurones supplying chick hind limb muscles. J Physiol 284: 371-389.

Law CO, Kirby RJ, Aghamohammadzadeh S, Furley AJ. 2008. The neural adhesion molecule TAG-1 modulates responses of sensory axons to diffusible guidance signals. Development 135: 2361-2371.

Lee R, Petros TJ, Mason CA. 2008. Zic2 regulates retinal ganglion cell axon avoidance of ephrinB2 through inducing expression of the guidance receptor EphB1. J Neurosci 28: 5910-5919.

Letourneau PC. 1975. Cell-to-substratum adhesion and guidance of axonal elongation. Dev Biol 44: 92-101.

Letourneau PC. 1978. Chemotactic response of nerve fiber elongation to nerve growth factor. Dev Biol 66: 183-196.

Letourneau PC, Condic ML, Snow DM. 1994. Interactions of developing neurons with the extracellular matrix. J Neurosci 14: 915-928.

Lindwall C, Fothergill T, Richards LJ. 2007. Commissure formation in the mammalian forebrain. Curr Opin Neurobiol 17: 3-14.

Llambi F, Causeret F, Bloch-Gallego E, Mehlen P. 2001. Netrin-1 acts as a survival factor via its receptors UNC5H and DCC. EMBO J 20: 2715-2722.

Luo Y, Raible D, Raper JA. 1993. Collapsin: A protein in brain that induces the collapse and paralysis of neuronal growth cones. Cell 75: 217-227.

Luria V, Krawchuk D, Jessell TM, Laufer E, Kania A. 2008. Specification of motor axon trajectory by ephrin-B:EphB signaling: Symmetrical control of axonal patterning in the developing limb. Neuron 60: 1039-1053.

Luskin MB, Shatz CJ. 1985. Studies of the earliest generated cells of the cat's visual cortex: Cogeneration of subplate and marginal zones. J Neurosci 5: 1062-1075.

Lyuksyutova AI, Lu CC, Milanesio N, King LA, Guo N, Wang Y, Nathans J, Tessier-Lavigne M, Zou Y. 2003.
Anterior-posterior guidance of commissural axons by Wnt-frizzled signaling. Science 302: 1984-1988.

Maness PF, Schachner M. 2007. Neural recognition molecules of the immunoglobulin superfamily: Signaling transducers of axon guidance and neuronal migration. Nat Neurosci 10: 19-26.

Marcus RC, Blazeski R, Godement P, Mason CA. 1995. Retinal axon divergence in the optic chiasm: Uncrossed axons diverge from crossed axons within a midline glial specialization. J Neurosci 15: 3716-3729.

Marcus RC, Mason CA. 1995. The first retinal axon growth in the mouse optic chiasm: Axon patterning and the cellular environment. J Neurosci 15: 6389-6402.

Marcus RC, Shimamura K, Sretavan D, Lai E, Rubenstein JL, Mason CA. 1999. Domains of regulatory gene expression and the developing optic chiasm: Correspondence with retinal axon paths and candidate signaling cells. J Comp Neurol 403: 346-358.

Marshak S, Nikolakopoulou AM, Dirks R, Martens GJ, Cohen-Cory S. 2007. Cell-autonomous TrkB signaling in presynaptic retinal ganglion cells mediates axon arbor growth and synapse maturation during the establishment of retinotectal synaptic connectivity. J Neurosci 27: 2444-2456.

Mason CA, Wang LC. 1997. Growth cone form is behaviorspecific and, consequently, position-specific along the retinal axon pathway. J Neurosci 17: 1086-1100.

Matthews BJ, Kim ME, Flanagan JJ, Hattori D, Clemens JC, Zipursky SL, Grueber WB. 2007. Dendrite self-avoidance is controlled by Dscam. Cell 129: 593-604.

McKerracher L, Chamoux M, Arregui CO. 1996. Role of laminin and integrin interactions in growth cone guidance. Mol Neurobiol 12: 95-116.

McLaughlin T, Hindges R, Yates PA, O’Leary DD. 2003. Bifunctional action of ephrin-B1 as a repellent and attractant to control bidirectional branch extension in dorsal-ventral retinotopic mapping. Development 130: 2407-2418.

Myers PZ, Bastiani MJ. 1993. Cell-cell interactions during the migration of an identified commissural growth cone in the embryonic grasshopper. J Neurosci 13: $115-126$.

Nakagawa S, Brennan C, Johnson KG, Shewan D, Harris WA, Holt CE. 2000. Ephrin-B regulates the Ipsilateral routing of retinal axons at the optic chiasm. Neuron 25: 599-610.

Nordlander RH, Singer M. 1982. Spaces precede axons in Xenopus embryonic spinal cord. Exp Neurol 75: 221-228.

Nordlander RH, Singer JF, Beck R, Singer M. 1981. An ultrastructural examination of early ventral root formation in amphibia. J Comp Neurol 199: 535-551.

Norris CRKalil K. 1990. Morphology and cellular interactions of growth cones in the developing corpus callosum. J Comp Neurol 293: 268-281.

O'Connor R, Tessier-Lavigne M. 1999. Identification of maxillary factor, a maxillary process-derived chemoattractant for developing trigeminal sensory axons. Neuron 24: $165-178$. 
Pasterkamp RJ, Peschon JJ, Spriggs MK, Kolodkin AL. 2003. Semaphorin 7A promotes axon outgrowth through integrins and MAPKs. Nature 424: 398-405.

Patel TD, Jackman A, Rice FL, Kucera J, Snider WD. 2000. Development of sensory neurons in the absence of NGF/TrkA signaling in vivo. Neuron 25: 345-357.

Pietri T, Eder O, Breau MA, Topilko P, Blanche M, Brakebusch C, Fassler R, Thiery JP, Dufour S. 2004. Conditional $\beta 1$-integrin gene deletion in neural crest cells causes severe developmental alterations of the peripheral nervous system. Development 131: 3871-3883.

Pike SH, Melancon EF, Eisen JS. 1992. Pathfinding by zebrafish motoneurons in the absence of normal pioneer axons. Development 114: 825-831.

Pittman AJ, Law MY, Chien CB. 2008. Pathfinding in a large vertebrate axon tract: Isotypic interactions guide retinotectal axons at multiple choice points. Development 135: $2865-2871$.

Plump A, Erskine L, Sabatier C, Brose K, Epstein C, Goodman C, Mason C, Tessier-Lavigne M. 2002. Slitl and Slit2 cooperate to prevent premature midline crossing of retinal axons in the mouse visual system. Neuron 33: $219-232$.

Rajagopalan S, Nicolas E, Vivancos V, Berger J, Dickson BJ. 2000. Crossing the midline: Roles and regulation of Robo receptors. Neuron 28: 767-777.

Ramon y Cajal S. 1995. Histology of the nervous system of man and vertebrates. (trans. N Swanson and LW Swanson), Vol 1: 532. Oxford University Press, New York.

Rangarajan R, Gong Q, Gaul U. 1999. Migration and function of glia in the developing Drosophila eye. Development 126: $3285-3292$.

Raper JA, Bastiani M, Goodman CS. 1983a. Pathfinding by neuronal growth cones in grasshopper embryos. I. Divergent choices made by the growth cones of sibling neurons. J Neurosci 3: 20-30.

Raper JA, Bastiani M, Goodman CS. 1983b. Pathfinding by neuronal growth cones in grasshopper embryos. II. Selective fasciculation onto specific axonal pathways. J Neurosci 3: 31-41.

Raper JA, Bastiani MJ, Goodman CS. 1984. Pathfinding by neuronal growth cones in grasshopper embryos. IV. The effects of ablating the $\mathrm{A}$ and $\mathrm{P}$ axons upon the behavior of the G growth cone. J Neurosci 4: 2329-2345.

Reichardt LF. 2006. Neurotrophin-regulated signalling pathways. Philos Trans R Soc Lond B Biol Sci 361: 15451564.

Renzi MJ, Wexler TL, Raper JA. 2000. Olfactory sensory axons expressing a dominant-negative semaphorin receptor enter the CNS early and overshoot their target. Neuron 2000 28: 437-447.

Ross LS, Parrett T, Easter SS Jr. 1992. Axonogenesis and morphogenesis in the embryonic zebrafish brain. J Neurosci 12: $467-482$.

Rougon G, Hobert O. 2003. New insights into the diversity and function of neuronal immunoglobulin superfamily molecules. Annu Rev Neurosci 26: 207-238.

Sabatier C, Plump AS, Le Ma, Brose K, Tamada A, Murakami F, Lee EY, Tessier-Lavigne M. 2004. The divergent Robo family protein rig- $1 /$ Robo 3 is a negative regulator of slit responsiveness required for midline crossing by commissural axons. Cell 117: 157-169.

Sabry JH, O'Connor TP, Evans L, Toroian-Raymond A, Kirschner M, Bentley D. 1991. Microtubule behavior during guidance of pioneer neuron growth cones in situ. J Cell Biol 115: 381-395.

Sakai JA, Halloran MC. 2006. Semaphorin 3d guides laterality of retinal ganglion cell projections in zebrafish. Development 133: 1035-1044.

Schmid RS, Maness PF. 2008. L1 and NCAM adhesion molecules as signaling coreceptors in neuronal migration and process outgrowth. Curr Opin Neurobiol 18: 245250.

Schmucker D, Clemens JC, Shu H, Worby CA, Xiao J, Muda M, Dixon JE, Zipursky SL. 2000. Drosophila Dscam is an axon guidance receptor exhibiting extraordinary molecular diversity. Cell 101: 671-684.

Schwander M, Shirasaki R, Pfaff SL, Muller U. 2004. Beta1 integrins in muscle, but not in motor neurons, are required for skeletal muscle innervation. J Neurosci 24: 8181-8191.

Schwarting GA, Kostek C, Ahmad N, Dibble C, Pays L, Püschel AW. 2000. Semaphorin 3A is required for guidance of olfactory axons in mice. J Neurosci 20: 7691-7697.

Scolnick JA, Cui K, Duggan CD, Xuan S, Yuan XB, Efstratiadis A, Ngai J. 2008. Role of IGF signaling in olfactory sensory map formation and axon guidance. Neuron 57: $847-857$.

Serafini T, Colamarino SA, Leonardo ED, Wang $\mathrm{H}$, Beddington R, Skarnes WC, Tessier-Lavigne M. 1996. Netrin-1 is required for commissural axon guidance in the developing vertebrate nervous system. Cell 87: 1001-1014.

Seth A, Culverwell J, Walkowicz M, Toro S, Rick JM, Neuhauss SC, Varga ZM, Karlstrom RO. 2006. belladonna/ (Ihx2) is required for neural patterning and midline axon guidance in the zebrafish forebrain. Development 133: $725-735$.

Siebert M, Banovic D, Goellner B, Aberle H. 2009. Drosophila motor axons recognize and follow a Sidesteplabeled substrate pathway to reach their target fields. Genes Dev. 23: 1052-1062.

Silver J, Edwards MA, Levitt P. 1993. Immunocytochemical demonstration of early appearing astroglial structures that form boundaries and pathways along axon tracts in the fetal brain. J Comp Neurol 328: 415-436.

Silver J, Lorenz SE, Wahlsten D, Coughlin J. 1982. Axonal guidance during development of the great cerebral commissures: descriptive and experimental studies, in vivo, on the role of preformed glial pathways. J Comp Neurol 210: $10-29$.

Singer M, Nordlander RH, Egar M. 1979. Axonal guidance during embryogenesis and regeneration in the spinal cord of the newt: The blueprint hypothesis of neuronal pathway patterning. J Comp Neurol 185: 1-21.

Snow DM, Brown EM, Letourneau PC. 1996. Growth cone behavior in the presence of soluble chondroitin sulfate proteoglycan (CSPG), compared to behavior on CSPG bound to laminin or fibronectin. Int J Dev Neurosci 14: $331-349$. 
J. Raper and C. Mason

Soba P, Zhu S, Emoto K, Younger S, Yang SJ, Yu HH, Lee T, Jan LY, Jan YN. 2007. Drosophila sensory neurons require Dscam for dendritic self-avoidance and proper dendritic field organization. Neuron 54: 403-416.

Song HJ, Ming GL, Poo MM. 1997. cAMP-induced switching in turning direction of nerve growth cones. Nature 388: $275-279$.

Speidel CC. 1933. Studies of living nerves. II. Activities of ameboid growth cones, sheath cells, and myelin segments, as reealed by prolonged observation of individual nerve fibers in frog tadpoles. Am J Anat 52: 1-79.

Sperry RW. 1943a. Effect of $180^{\circ}$ rotation of the retinal field on visuomotor coordination. J Exp. Zool 92: 263-279.

Sperry RW. 1943b Visuomotor coordination in the newt (Triturus viridescens) after regeneration of the optic nerve. J Comp Neurol 79: 33-35.

Sperry RW. 1963. Chemoaffinity in the orderly growth of nerve fiber patterns and connections. PNAS 50: $703-710$.

Sretavan DW, Feng L, Pure E, Reichardt LF. 1994. Embryonic neurons of the developing optic chiasm express L1 and CD44, cell surface molecules with opposing effects on retinal axon growth. Neuron 12: 957-975.

Stein ETessier-Lavigne M. 2001. Hierarchical organization of guidance receptors: silencing of netrin attraction by slit through a Robo/DCC receptor complex. Science 291: $1928-1938$.

Stoeckli ET, Landmesser LT. 1995. Axonin-1, Nr-CAM, and $\mathrm{Ng}$-CAM play different roles in the in vivo guidance of chick commissural neurons. Neuron 14: 1165-1179.

Stork T, Thomas S, Rodrigues F, Silies M, Naffin E, Wenderdel S, Klambt C. 2009. Drosophila Neurexin IV stabilizes neuron-glia interactions at the CNS midline by binding to Wrapper. Development 136: 1251-1261.

Stuermer CA, Bastmeyer M. 2000. The retinal axon's pathfinding to the optic disk. Prog Neurobiol 62: 197214.

Suter DM, Forscher P. 2000. Substrate-cytoskeletal coupling as a mechanism for the regulation of growth cone motility and guidance. J Neurobiol 44: 97-113.

Taghert PH, Bastiani MJ, Ho RK, Goodman CS. 1982. Guidance of pioneer growth cones: Filopodial contacts and coupling revealed with an antibody to Lucifer Yellow. Dev Biol 94: 391-399.

Takahashi H, Sakuta H, Shintani T, Noda M. 2009. Functional mode of FoxD1/CBF2 for the establishment of temporal retinal specificity in the developing chick retina. Dev Biol 331: 300-310.

Taniguchi M, Nagao H, Takahashi YK, Yamaguchi M, Mitsui S, Yagi T, Mori K, Shimizu T. 2003. Distorted odor maps in the olfactory bulb of semaphorin 3Adeficient mice. J Neurosci 23: 1390-1397.

Tello F. 1923. Les différenciations neuronales dans l'embryon du poulet, pendant les premiers jours de l'incubation. Trav Lab Invest biol Univ Madrid 21: 1-93.

Tennyson VM 1970. The fine structure of the axon and growth cone of the dorsal root neuroblast of the rabbit embryo. J Cell Biol 44: 62-79.

Thanos S, Bonhoeffer F, Rutishauser U. 1984. Fiber-fiber interaction and tectal cues influence the development of the chicken retinotectal projection. Proc Natl Acad Sci U S A 81: 1906-1910.

Tosney KW, Landmesser LT. 1985. Growth cone morphology and trajectory in the lumbosacral region of the chick embryo. J Neurosci 5: 2345-2358.

Vainio S, Heikkilä M, Kispert A, Chin N, McMahon AP. 1999. Female development in mammals is regulated by Wnt-4 signaling. Nature 397: 405-409.

Wadsworth WG, Bhatt H, Hedgecock EM. 1996. Neuroglia and pioneer neurons express UNC-6 to provide global and local netrin cues for guiding migrations in C. elegans. Neuron 16: 35-46.

Walsh C, Guillery RW. 1985. Age-related fiber order in the optic tract of the ferret. J Neurosci 5: 3061-3069.

Wang X, Zhang W, Cheever T, Schwarz V, Opperman K, Hutter H, Koepp D, Chen L. 2008. The C. elegans L1CAM homologue LAD-2 functions as a coreceptor in MAB-20/Sema2 mediated axon guidance. J Cell Biol 180: $233-246$.

Weiss PA. 1934. In vitro experiments on the factors determining the course of the outgrowing nerve fiber. $J$ Exp Zool 68: 393-448.

Weiss PA. 1936. Selectivity controlling the centralperipheral relations in the nervous system. Biol Rev 11: 494-531.

Weiss PA. 1945. Experiments on cell and axon orientation in vitro: The role of collodal exudates in tissue organization. J Exp Zool 100: 353-386.

Wiencken-Barger AE, Mavity-Hudson J, Bartsch U, Schachner M, Casagrande VA. 2004. The role of L1 in axon pathfinding and fasciculation. Cereb Cortex 14: $121-131$.

Whitesides JG 3rd, LaMantia AS. 1996. Differential adhesion and the initial assembly of the mammalian olfactory nerve. J Comp Neurol 373: 240-254.

Whitlock KE, Westerfield M. 1998. A transient population of neurons pioneers the olfactory pathway in the zebrafish. J Neurosci 18: 8919-8927.

Wigglesworth VB. 1953. The origin of sensory neurones in an insect, Rhodnius prolixus (Hemiptera). Quart J Microsc Sci 94: 93-112.

Williams EJ, Walsh FS, Doherty P. 1994. Tyrosine kinase inhibitors can differentially inhibit integrin-dependent and CAM-stimulated neurite outgrowth. J Cell Biol 124: 1029-1037.

Williams SE, Mann F, Erskine L, Sakurai T, Wei S, Rossi DJ, Gale NW, Holt CE, Mason CA, Henkemeyer M. 2003. Ephrin-B2 and EphB1 mediate retinal axon divergence at the optic chiasm. Neuron 39: 919-935.

Williams SE, Grumet M, Colman DR, Henkemeyer M, Mason CA, Sakurai T. 2006. A role for Nr-CAM in the patterning of binocular visual pathways. Neuron 50: 535-547.

Wilson SW, Ross LS, Parrett T, Easter SS Jr. 1990. The development of a simple scaffold of axon tracts in the brain of the embryonic zebrafish, Brachydanio rerio. Development 108: $121-145$.

Wilson SI, Shafer B, Lee KJ, Dodd J. 2008. A molecular program for contralateral trajectory: Rig-1 control by LIM homeodomain transcription factors. Neuron 59: $413-424$. 
Windle WF, Austin MF. 1935. Neurofibrillar development in the central nervous system of chick embryos up to 5 days' incubation. J Comp Neurol 63: 431-463.

Wolman MA, Regnery AM, Becker T, Becker CG, Halloran MC. 2007. Semaphorin3D regulates axon axon interactions by modulating levels of L1 cell adhesion molecule. J Neurosci 27: 9653-9663.

Yamamoto M, Hassinger L, Crandall JE. 1990. Ultrastructural localization of stage-specific neurite-associated proteins in the developing rat cerebral and cerebellar cortices. J Neurocytol 19: 619-627.

Yang L, Garbe DS, Bashaw GJ. 2009. A frazzled/DCCdependent transcriptional switch regulates midline axon guidance. Science 324: 944-947.

Zhou L, Bar I, Achouri Y, Campbell K, De Backer O, Hebert JM, Jones K, Kessaris N, de Rouvroit CL, O’Leary D, et al. 2008. Early forebrain wiring: genetic dissection using conditional Celsr3 mutant mice. Science 320: 946-949. 


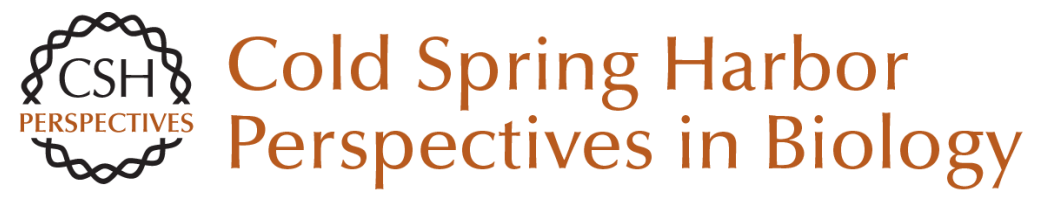

\section{Cellular Strategies of Axonal Pathfinding}

Jonathan Raper and Carol Mason

Cold Spring Harb Perspect Biol 2010; doi: 10.1101/cshperspect.a001933 originally published online June 30, 2010

\section{Subject Collection Neuronal Guidance}

Mechanisms and Molecules of Neuronal Wiring: A Primer

Alex L. Kolodkin and Marc Tessier-Lavigne

Guidance Molecules in Axon Pruning and Cell

Death

Pierre Vanderhaeghen and Hwai-Jong Cheng

Initiating and Growing an Axon

F. Polleux and William Snider

Navigating Intermediate Targets: The Nervous System Midline

Barry J. Dickson and Yimin Zou

Cellular Strategies of Axonal Pathfinding

Jonathan Raper and Carol Mason

Guidance Molecules in Axon Regeneration

Roman J. Giger, Edmund R. Hollis II and Mark H. Tuszynski

Signaling from Axon Guidance Receptors Greg J. Bashaw and Rüdiger Klein

Visual Map Development: Bidirectional Signaling, Bifunctional Guidance Molecules, and Competition

David A. Feldheim and Dennis D. M. O'Leary
Wiring the Brain: The Biology of Neuronal

Guidance

Alain Chédotal and Linda J. Richards

Guidance Molecules in Synapse Formation and

Plasticity Kang Shen and Christopher W. Cowan

The Growth Cone Cytoskeleton in Axon

Outgrowth and Guidance

Erik W. Dent, Stephanie L. Gupton and Frank B. Gertler

Topographic Mapping--The Olfactory System Takeshi Imai, Hitoshi Sakano and Leslie B. Vosshall

Self-avoidance and Tiling: Mechanisms of

Dendrite and Axon Spacing Wesley B. Grueber and Alvaro Sagasti

Trafficking Guidance Receptors Bettina Winckler and Ira Mellman

Axon Guidance Molecules in Vascular Patterning Ralf $H$. Adams and Anne Eichmann

Human Genetic Disorders of Axon Guidance Elizabeth C. Engle

For additional articles in this collection, see http://cshperspectives.cshlp.org/cgi/collection/

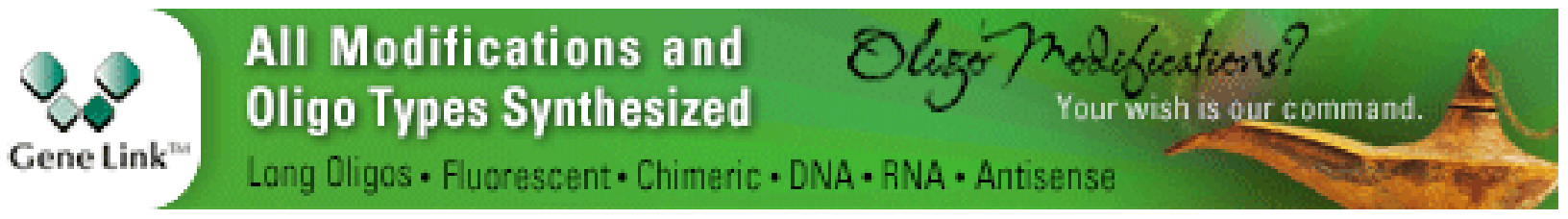

Copyright @ 2010 Cold Spring Harbor Laboratory Press; all rights reserved 